\title{
The Canon of Holy Scripture: Four Vital Vectors in Plotting a Better Understanding of this Essential Doctrine
}

\author{
Michael A. Milton, $\mathrm{PhD}^{1}$ \\ ${ }^{1}$ Affiliation not available
}

October 4, 2021

\begin{abstract}
The author advances that contemporary Western culture is marked by a self-induced ignorance of Scripture, as well as a secular age antagonism. He proposes by pointing to four vector for recovery the doctrine of canonicity. The author concludes with a personal appeal.
\end{abstract}

There is evidence of not only Biblical illiteracy in the Church but also an inability to give an apologetic for why the Bible is God' Word. The Apostle John is not ambiguous in the least:

In the beginning was the Word, and the Word was with God, and the Word was God. He was at the beginning with God. All things were made through him, and without him was not any thing made that was made. In him was life, and the life was the light of men. The light shines in the darkness, and the darkness has not overcome it. And the Word became flesh and dwelt among us, and we have seen his glory, glory as of the only Son from the Father, full of grace and truth. (John 1:1-4, 14 ESV).

\section{Dull or Dazzling?}

Some things appear dull until we draw closer. Then, upon closer examination, the dull becomes dazzling.

Geometry was like that for me. Geometry is a relatively small god on the pantheon of mathematical deities. However, I was not too fond of the very thought of it. My seventh-grade geometry teacher perceived that I was indifferent or disinterested in what she felt was "the wonderful world" of geometry. A fantastic educator (and an effective evangelist for her subject), Mrs. Engle* wanted every student to be as excited about geometry as she was. I was apparently easy to read in my subdued enthusiasm for vectors and triangles. She took me aside to talk about it. I agreed to her plan, though it sounded far-fetched. Only now do I see her wisdom and thank God for her commitment to education. She and Mr. Engle* picked me up from our rural isolated home, and drove an hour, on a Saturday morning trip, to an art museum. My teacher even arranged a time to study representative works of J.M.W. Turner carefully, John Constable, Vincent van Gogh, and Claude Monet ("my favorite artists," I had informed her earlier). She directed my attention to the points, planes, and polygons in Monet's Water "Lilies" (1916), Turner's "The Fighting Temeraire" (1839), and Constable's "Study of Clouds" (1822). I became appreciative of the undeniable presence of form and shape in paintings. As an artist, I continue to paint by thinking of geometric bodies within the drawing. Geometry came alive and stayed with me. My irresponsible grade of "D" became a relatively respectable "B-." And the dull became dazzling. 


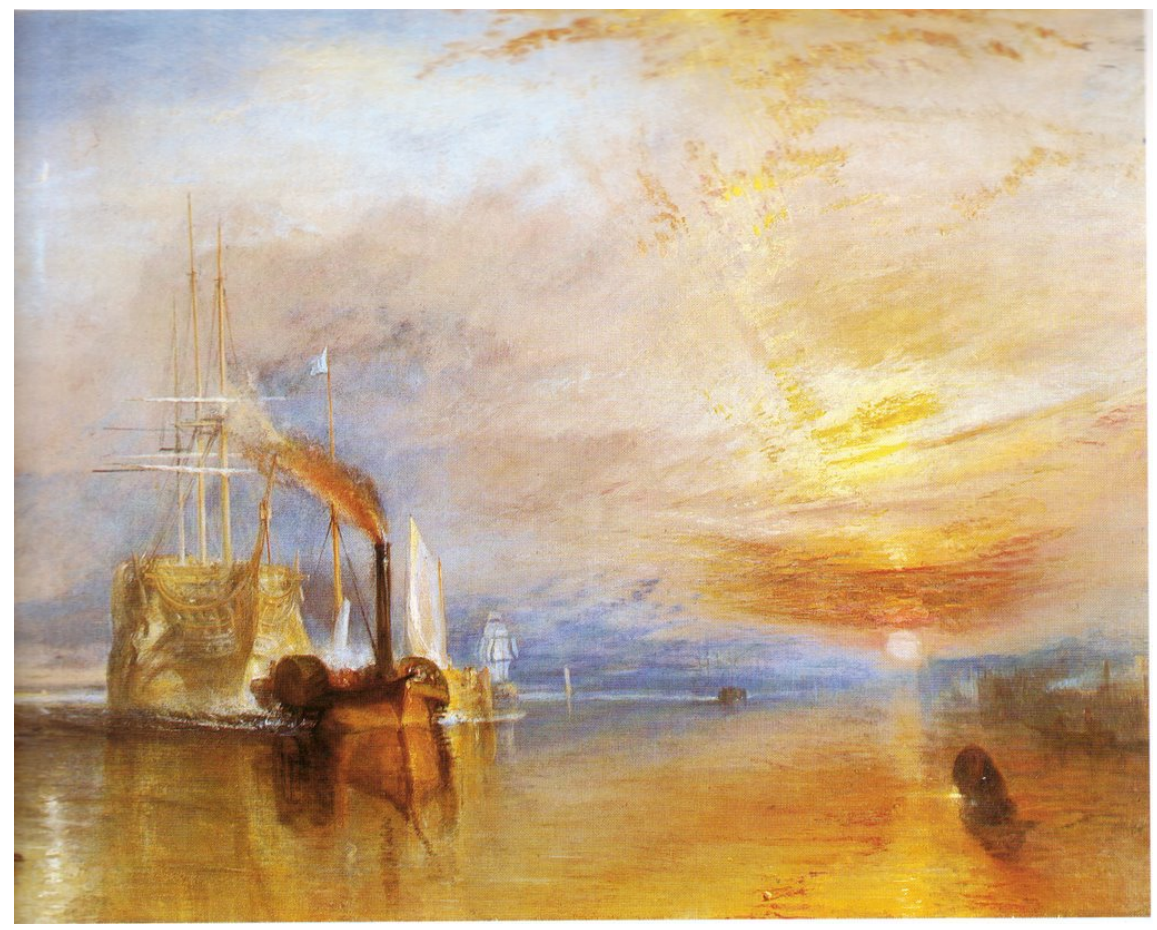

Figure 1: The Fighting Temeraire (1839). English. J.M.W. Turner (1775-1851). National Gallery, London.

\section{The Canon Debated}

There are undoubtedly some who are reading these words who might be tempted to believe the study of Canon is dull . Perhaps, you think of the Canon of Scripture as something only academics chat about in dark, book-lined libraries. Maybe you believe that it is of little value to your life as a believer. Well, if that is you, I want to say: draw closer. The doctrine of the God-breathed Word from Another World is anything but dull ("A Word from Another World" was a favorite expression of my seminary professor and mentor, the late Robert L. Reymond, Ph.D.). The phrase conveys, at once, a mystery, a supernatural origin, and a revelation that necessarily transcends Man and yet is mercifully accessible to Man. Yet, an incorrect or absent perception about the Christian (and, in large part, Judeo-Christian) doctrine of the Canon of Scripture is hardly a new threat to the Faith. Nevertheless, few doctrines, once neglected, can have more destructive spiritual consequences. Canonicity represents the activity of God in the Church in giving us his Word, recording that Word, and through the power of the Holy Spirit, distributing that Word to the ends of the earth. There has never been a time when we in the evangelical churches needed a higher view of Scripture. Yet, we all recognize that we are living in a dry land:

"Because God has made himself known in his Word, a commitment to a high view of Scripture is of paramount importance. Yet, sadly, more and more people - not only from outside the Church but also from within - are denying the complete truthfulness of God's Word" (Sproul et al. 2016).

Knowing the canonical story behind the Holy Bible helps us defend the Faith, and as the Lord opens hearts, it supports the advance of the Kingdom of God. The Christian faith is not, firstly, about a feeling, a religious duty, or a philosophy of life. Christianity is about Christ, who is revealed as the Eternal Word in the flesh and revealed in the supernatural Word written for our salvation (Palmer 2010). It is in this sense that one approaches the Canon of Scripture. The Canon of Scripture is a doctrine of divine origin. The Bible is as miraculous as the creation of the heavens and the earth, an iron ax-head floating on top of the water, the 
dead man Lazarus walking forth in his burial winding-sheet, the Virgin birth, or the resurrection of our God and Savior, Jesus \#sChrist. This is how we must approach this critical subject, but approach it we must. For there are priceless pearls of great wisdom in the treasure chest of Canon of Scripture.

As I prepared to write this article for the benefit of the Body of Christ, I imagined a fellow believer sitting before me and asking, "Precisely what is it about the canon of Scripture that you think I should know, and why?" I want to both posit that question and seek to respond. That is a question that has, indeed, come to me over the years of my vocation. So here are four truths we can know about the Canon of Scripture to help us trust the Bible, defend the Faith, and unleash its reality in our day.

\section{The Canon Defined}

The Canon of the Old Testament was set by the time of Jesus. (Bible 1970)Jesus recognized the canonicity of the Old Testament, that is, the very collection of books that you have in your Bible today. The doctrine of Christ will naturally, effortlessly, cause the believer to develop a high view of Scripture. Infallible and inerrant are just so because Jesus believed it. Please make no mistake about it: Jesus is our ultimate source of knowledge about the Canon of Scripture. Some Scriptures in which Jesus appeals to the Word of God and declares Himself as the authentication for the Canon of Scripture include Matt. 7:24-29, Mark 8:38, Luke 9:26, 8:21, John 8:31, 47, 51, 10:27, 12:47-50, 14:15, 21, 23f, 15:7, 10, 14, 17:6, 8, 17. No one can deny that the New Testament is replete with examples of Jesus and the Apostles referring to the Old Testament books as the very Word of God. In a similar self-attesting way, the New Testament speaks of itself as on par with the Old Testament Scriptures. By the time of the early Church, the authentic epistles and histories (viz., the Gospels, Epistles, and Acts) written by the Apostles and their aids were used and received as the Word of God. This is because we must not suppose that the early Church received these as divine by Man, but only by the power of the Holy Spirit. We shall address this further as we move forward. This leads me to attend to some essential foundation stones of the canonicity of Holy Scripture before erecting any further points of doctrine.

So, before we go any further, let us make sure we speak about the same thing. Let us begin with definitions.

\section{The Word "Canon"}

Our English Word, "Canon," is derived from a Hebrew and Greek word denoting a reed or a cane.(Kruger 2013) So we would call it a "ruler," like the old wooden ruler you had in your supplies for third grade. Canon , then, grew out of a word that means something straight, or somethingto keep straight, a standard of truth, the measure of reality: "It came to be applied to the Scriptures, to denote that they contained the authoritative rule of faith and practice, the standard of doctrine and duty" (Easton 1894). In this way of thinking, the Canon of Scripture refers to measuring the God-breathed truths revealed to men.

\section{A Defense for of the Canon of Holy Scripture}

So, the word "canon" is the accurate measurement of a thing against the model in the most general meaning. In the case of Holy Scripture, the written Word of God must equate to the Holy Spirit-inspired ("Godbreathed") Word of God. This is the meaning of 2 Timothy 3:16:

All Scripture is given by inspiration of God, and is profitable for doctrine, for reproof, for correction, for instruction in righteousness, that the man of God may be complete, thoroughly equipped for every good work (2 Timothy 3:16 NKJV).

Thus, the Word of God is Inscripturated by God, as the Reverend Jonathan Witherspoon put it (Wolfe 2016) imminent Presbyterian minister, scholar, public theologian, Princeton president, and only clergyman to sign the Declaration of Independence gave us solid and valuable work. The eternal Word of God became 
flesh and became - for us, and our salvation - the Word made accessible. Israel was prohibited from seeking to know God by making images. Instead, we were to think thoughts after God. The People of Israel were to meditate upon God through his Word, which he gave them. Abundant life and eternal life came not from manufactured religious attempts for atonement but rather through the Word of God read, taught, preached, song, and shared with others, beginning with our own families. Scholars such as the late Neil Postman (2931-2003), a Jewish academic, and Jacque Ellul (1912-1994), a French Christian and university professor, considered the age of image and technology (i.e., image divorced from the personal exchange of ideas) as threats to the Word and to postmodern man's intellectual capacity to read, synthesize different ideas, and make conclusions. Their now-classic works, such as Postman's Entertaining Ourselves to Death, and Ellul's La technique ou l'enjeu du siècle (1954), The Technological Society (1990) raises the concern that deemphasizing reading, typography, and books, and reverting to image-based communication is a significant regression to pre-Reformation days. For God did not choose an image, but the Word to reveal Himself and His plans. The Bible is God's message to Man "in the form of the written word." This is quite different from learning the Gospel by stained glass windows only (the case in the image-based societies before John Wycliffe, Martin Luther, and other reformers. Instead, those sixty-six books of the Old and New Testament are measured by an inerrant and infallible standard, the very Word of God. So, we may say,

The Canon of Holy Scripture is the divinely authorized collection of writings - no more and no less-than are indeed God's Word revealed to humankind for God's gracious purposes, through the supernatural agency of the Holy Spirit.

Now. How did Canon come to be?

\section{The Canon Decided}

Was there one big meeting in history when the Canon of Scripture was set?11 No. While there were essential councils of both the Hebrews and the early church fathers, no single gathering of representatives of the Church issued the final Word on the Word of God.

"After the Maccabean persecution, the history of the formation of the Canon is merged in the history of its contents. The Old Testament appears from that time as a whole. The complete Canon of the New Testament, as commonly received at present, was ratified at the Third Council of Carthage (A.D. 397), and from that time was accepted throughout the Latin Church" ("The Canon of Scripture," Smith's Bible Dictionary).

The reason is apparent. The Church did not create the Holy Bible. The Church, in both the Old and New Covenants, was revealed by the Bible.

The matter of "who decides what is in and what is out" leads the student of Canon to a perennial debate within the Church. The division of thought could be characterized as the "Community or the Received" debate(Peckham 2016).

\section{Is the Canon of Scripture a Product of the Community?}

In this view, held by many Roman Catholic believers and some in Protestant denominations, the Canon of Scripture is set, not by one gathering of church leaders on a specific date, but, instead, is authorized by its usefulness and acceptance in the churches. Here is a description of the view by a Roman Catholic source, set forth, in my opinion, in the most gracious way, allowing room for both sides of the argument:

The Early Church Fathers understood the Canon of Scripture was set by God. They also knew that God communicated this fact through the Catholic Church. Many of them lived during the period when this was done. There was no consensus, as some seem to think. Eusebius tells us that the book of 1 Clement was read 
in the churches from the early days until his own time (Church History 3:16 [A.D. 325]) (Farma, The Early Church Fathers on Church Canon) (Kruger 2012).

This via media view has much to commend. However, this explanation stops short of affirming the miracle of the Canon of Scripture.

\section{Is the Canon both created and received through the work of the Holy Spirit?}

Yes. The Canon of both the Old and New Testament developed through time, in localities, by mortal writers, yet all by the supernatural work of the Holy Spirit. The Bible was and is received as the Word of God because it is the Word of God. This is the message of those (I am among them) who confess Scripture because we believe that the Holy Spirit in a believer (or the Spirit working upon the heart of an unbeliever) recognizes Himself in His Word. There is a supernatural connection that is not a nebulous "burden in the bosom" of Latter-Day Saints, but, relatively, a Spiritual power from on high that converts, convinces, condemns, corrects, and, in all ways, glorifies Jesus Christ as the Word of God. No Reformed confessional document espouses the miracle of the sixty-six books of the Holy Bible any better than the Westminster Confession of Faith (1646) (Carruthers 1897).

The following is from the Westminster Confession of Faith (1646), 1:IV:

IV. The authority of the Holy Scripture, for which it ought to be believed and obeyed, dependeth not upon the testimony of any man or Church, but wholly upon God, (who is truth itself,) the author thereof: and therefore, it is to be received, because it is the Word of God.

Some have argued that this is circuitous reasoning and, therefore, a logical fallacy. Others have called it biblicism. The charges would be credible but for one immovable and incontestable reason:The Person of Jesus Christ. If Christ Jesus is the resurrected, ascended, and reigning Lord of Lords and King of Kings, then the origin, Canon, and purposes of Holy Scripture are altogether divine: "And beginning with Moses and all the Prophets, he interpreted to them in all the Scriptures the things concerning himself" (Luke 24:27 ESV).

The believing community did not select the books of the Bible for their purposes. God brought forth the books of the Bible for His intentions (I owe the concept of "intentions" concerning the definition of Canon to Dr. Michael Kruger in his Michael J. Kruger, "The Definition of the Term 'Canon, " p, [Kruger, 2012]).

\section{The Canon Defended}

The canonicity of the Bible does not need me or any other to defend its divine nature. The heavenly essence of Holy Scripture is its citadel. 


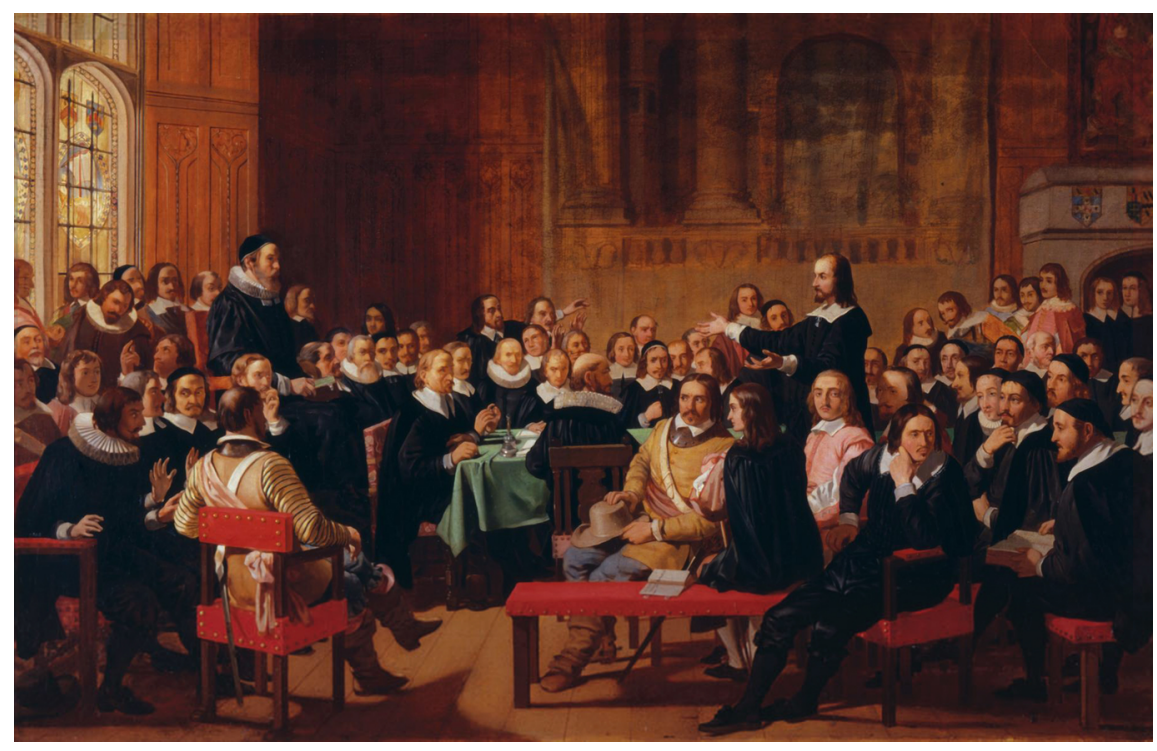

Figure 2: Assertion of Liberty of Conscience by the Independents of the Westminster Assembly of Divines, 1847. English. John Rogers Herbert, RA (1810-1890).

The Bible was God's Word before the beginning of the World. The Logos, our Lord Jesus Christ, is the Word of God personified. His presence and teaching are the fullness of that Word. Yet, the Word came to be recorded. God desired that humanity have a special revelation from heaven and gave us the Bible. We must remember that the Word of God was already the Word of God before the Old Testament prophet heard it and preached it. There is no human agency to either commission words as the Word of God or take words away.

"The Canon of the New Testament was completed when the last authoritative book was given to any church by the apostles, and that was when John wrote the Apocalypse, about A.D. 98" (Warfield 1948).

The Word often used to describe the present state of the Canon is "closed." Far more preferred is the term, "completed." No human, no Church council closed the Sacred Text. The Lord God completed it.

\section{Conclusion}

The Canon of Scripture is the divinely authorized collection of sacred text - though debated - is defined, decided, and defended by the One who breathed forth its power, assembled, and completed for God's mission in the World.

The Westminster Confession of Faith (1.6) says,

Fi. Perhaps there is no greater self-validation of the Word of God than Hebrews 4:12:

"For the word of God is living and powerful, and sharper than any two-edged sword, piercing even to the division of soul and spirit, and joints and marrow, and is a discerner of the thoughts and i prayers wwwë\$fesss

ntents of the heart." 
This leaves us with one final Word on the Canon of Scripture: What is the place of the Word of God in your life? For some, it is dull. But, for those who have received Jesus Christ as Lord, the Canon of Scripture is nothing short of dazzling.

\section{BIBLIOGRAPHY}

Anderson, Bernhard W., Bruce Manning Metzger, and Roland Edmund Murphy. 1991. The New Oxford Annotated Bible with the Apocryphal/Deuterocanonical Books. New York: Oxford University Press.

Beckwith, R. T. 2008. The Old Testament Canon of the New Testament Church: And Its Background in Early Judaism. Wipf \& Stock Publishers. https://books.google.com/books?id=7-RLAwAAQBAJ.

Coogan, Michael David, Marc Zvi Brettler, Carol A. Newsom, and Pheme Perkins. 2001a. The New Oxford Annotated Bible with the Apocryphal/Deuterocanonical Books . Oxford Oxford University Press, 2001.

- 2001b. The New Oxford Annotated Bible with the Apocryphal/Deuterocanonical Books . Oxford Oxford University Press, 2001.

. 2001c. The New Oxford Annotated Bible with the Apocryphal/Deuterocanonical Books . Oxford Oxford University Press, 2001.

Harris, R. Laird. 2008. Inspiration and Canonicity of the Scriptures . Wipf and Stock Publishers.

Hoole, Charles H. 1888a. The Classical Element in the New Testament Considered as a Proof of Its Genuineness : With an Appendix on the Oldest Authorities Used in the Formation of the Canon. London ; New York: Macmillan.

1888b. The Classical Element in the New Testament Considered as a Proof of Its Genuineness : With an Appendix on the Oldest Authorities Used in the Formation of the Canon . London ; New York: Macmillan.

"Kruger - 2012 - THE DEFINITION OF THE TERM 'CANON.' Pdf." n.d. Accessed September 19, 2021. https://legacy.tyndalehouse.com/Bulletin/63=2012/01-Kruger20.pdf.

Kruger, Michael J. 2012. "The Definition of the Term 'Canon."'Tyndale Bulletin 63, no. 1: 1-20. https://legacy.tyndalehouse.com/Bulletin/63=2012/01-Kruger20.pdf.

McDonald, Lee Martin, and James A. Sanders. 2002. The Canon Debate . Peabody, Mass.: Hendrickson Publishers.

Metzger, Bruce M. 1997. The Canon of the New Testament: Its Origin, Development, and Significance . Oxford University Press on Demand. files/5187/books.html.

Mitchell, E. C. 1880. The Critical Handbook: A Guide to the Study of the Authenticity, Canon, and Text of the Greek New Testament. Andover: Warren F. Draper.

Peckham, John, and Craig G. Bartholomew. 2016. Canonical Theology : The Biblical Canon, Sola Scriptura, and Theological Method .

Sitterly, Charles Fremont. 1914. The Canon, Text, and Manuscripts of the New Testament: Illustrated with Tables, Facsimile Plates and Survey of the Earliest MSS . New York: Methodist Book Concern.

Smith, Gordon T. 2015. The Voice of Jesus: Discernment, Prayer and the Witness of the Spirit . Intervarsity Press.

Society, American Bible. 1979. Good News Bible: With Deuterocanonicals/Apocrypha: The Bible in Today's English Version. New York: American Bible Society. 
Sproul, R. C., Alistair Begg, Mark Dever, Kevin DeYoung, Sinclair B. Ferguson, Michael J. Kruger, R. Albert Mohler Jr, Stephen J. Nichols, Carl R. Trueman, and William Barrick. 2016. The Inerrant Word: Biblical, Historical, Theological, and Pastoral Perspectives . Crossway.

Vasholz, Robert I. 1990. The Old Testament Canon in the Old Testament Church: The Internal Rationale for Old Testament Canonicity. Ancient Near Eastern Texts and Studies 7. Lewiston, N.Y., USA: E. Mellen Press.

Warfield, Benjamin B. 2021. "The Formation of the Canon of the New Testament." Bible Research , September. http://bible-researcher.com/warfield2.html.

Wolfe, Stephen. 2016. "John Witherspoon and Reformed Orthodoxy: Reason, Revelation, and the American Founding." LSU Master's Theses, January. https://digitalcommons.lsu.edu/gradschool_theses/1807.

\section{References}

Sproul, RC, Alistair Begg, Mark Dever, Kevin DeYoung, Sinclair B Ferguson, Michael J Kruger, R Albert Mohler Jr, et al. 2016. The Inerrant Word: Biblical, Historical, Theological, and Pastoral Perspectives. Crossway.

Palmer, Grant H. 2010. "Grant H. Palmer". Midwestern Theological Seminary Journal Spring.

Bible, Holy. 1970. "Old Testament". Oxford-Cambridge.

Kruger, Michael. 2013. "The Definition of the Term 'Canon". Tyndale Bulletin 63 (1): 1-20.

Easton, Matthew George. 1894. Illustrated Bible Dictionary, and Treasury of Biblical History, Biography, Geography, Doctrine, and Literature. T. Nelson.

Wolfe, Stephen Michael. 2016. "John Witherspoon and Reformed Orthodoxy: Reason, Revelation, And The American Founding". Master's thesis, Louisiana State University.

Peckham, John. 2016. Canonical Theology: The Biblical Canon, Sola Scriptura, and Theological Method. Wm. B. Eerdmans Publishing.

Kruger, Michael J. 2012. Canon Revisited: Establishing the Origins and Authority of the New Testament Books. Crossway.

Carruthers, William. 1897. The Shorter Catechism of the Westminster Assembly of Divines: Being a Facsimile of the First Edition. Publication office of the Presbyterian church of England.

Warfield, Benjamin B. 1948. "The Formation of the Canon of the New Testament". The Inspiration and Authority of the Bible, 411-16.

Assembly, Westminster. 1994. The Westminster Confession of Faith. Jazzybee Verlag. 